\title{
Microfinance and Inequality
}

\author{
Hisako Kai \\ Kobe University \\ 2-1, Rokkodai, Nada-Ku, Kobe 657-8501, Japan \\ E-mail: hisako.kai.kobe@gmail.com \\ Shigeyuki Hamori (Corresponding Author) \\ Kobe University \\ 2-1, Rokkodai, Nada-Ku, Kobe 657-8501, Japan \\ Email: hamori@econ.kobe-u.ac.jp
}

\begin{abstract}
The paper examines the relationship between microfinance and inequality by providing a cross-country empirical study of 61 developing countries. We show that microfinance plays an important role in creating a financial system endowed with the equalizing effect. Thus far, only a few single-country analyses of the impact of microfinance on inequality have been performed. To the best of our knowledge, our study is the first to indicate the universality of the equalizing effect of microfinance by applying the cross-country methodology. We find that microfinance can lower inequality and that poorer countries need to focus more on the equalizing effects of microfinance.
\end{abstract}

Keywords: Microfinance, Inequality, Impact Analysis at Macro Level 


\section{Introduction}

The income difference between the rich and the poor is rather significant in developing regions such as Latin America and Africa, causing serious problems in their societies. High income inequality in poor countries leads to crime and political instability and hampers the processes of economic development and poverty reduction. In developing countries, high inequality is often due to an imperfect financial market. Owing to immature financial regulations and poor administration of justice, moral hazard and adverse selection are rampant in these countries. Moreover, poor nations are fragile in the face of external shocks; since they are dependent on the agriculture industry, they face higher external risks. Accordingly, credit rationing takes place, since the market excludes the poor without collateral. This is one of the main reasons for high inequality in poor countries. In order to ease inequality and develop the financial sector, it is necessary to deal with such market failures.

Financial deepening (or the development of financial markets) is considered a powerful tool for lowering inequality, and it has recently been analyzed from both theoretical and empirical perspectives. However, theoretical studies on financial deepening have not reached a uniform conclusion and have been controversial. Some argue that financial deepening leads to efficient credit allocation and reduction of risk through the diversified investment and information production of financial intermediaries, which stimulates economic development and lowers inequality. Further, financial depth eases the credit constraints on the poor and increases their productive assets and productivity, thus contributing to poverty reduction (World Bank, 2001; Jalilian \& Kirkpatrick, 2002; Kai \& Hamori, 2009).

However, others argue that financial deepening only benefits the rich, thus increasing inequality. Beck, Demirgüç-Kunt, and Levine (2004) point out that since the poor depend mainly on informal finance such as borrowing from relatives or friends, the development of the financial sector is beneficial only to the wealthy. Moreover, financial depth lowers inequality solely during late-stage development, whereas financial deepening increases inequality in the early stages of development. This occurs because only the wealthy have access to the financial market (Greenwood \& Jovanovic, 1990, cited in Beck et al., 2004).

Only a few empirical studies have been conducted on this subject. Although most of these studies indicate that financial depth lowers inequality, a more detailed analysis is required ( $\mathrm{Li}$ et al., 1998; Beck et al., 2004).

As such, since the impact of overall financial depth on inequality seems to be obscure, we focus on the role of microfinance as a tool for financial depth endowed with the equalizing effect. Since microfinance directly eases the credit constraints on the poor, it is expected to lower inequality.

As a financial service for the poor, microfinance is largely applied in developing countries as low-rate finance, using the unique technique of group lending. Group lending is a financial service that offers loans to groups of borrowers who are jointly liable for the loans. Microfinance institutions (MFIs) transfer the opportunity cost to borrowers by allowing them to carry out screening and monitoring. Group members screen each other's repayment ability, 
which eases adverse selection. They also monitor each other, which mitigates moral hazard. Accordingly, lenders need not cover the high opportunity cost that is normally required for providing loans to the poor, and they can also achieve a low default rate. Since future loan access is possible only after borrowers have repaid their earlier loans, microfinance has a dynamic incentive-borrowers' clients can repay the loans. Using these effective mechanisms, microfinance offers loans to poor people who were initially excluded from the formal financial market because they were not creditworthy. Microfinance eases credit constraints and plays a significant role in the financial markets of developing countries.

Microfinance gives the poor access to financial services and allows them to make investments and diversify their business, thus leading to income increases. It not only offers financial services but also training in various disciplines, which enables borrowers to increase their productivity. They are able to cope with external shocks and achieve consumption smoothing. As such, microfinance enables the poor to increase their income, consumption, and productivity, which helps reduce inequality.

Ahlin and Jiang (2008) describe a model in which the adoption of microfinance is considered a financial development and show that microfinance decreases inequality. According to them, microfinance lowers inequality by increasing the income of the poor and lowering the income of the wealthy, since the wages paid by employers increase. Green, Kirkpatrick, and Murinde (2006) argue that improvement in the financial access of the poor can directly enhance poverty reduction, since an imperfect financial market, which excludes the poor, is an important factor that affects poverty (Stiglitz, 1998).

As such, although the equalizing effect of microfinance can be explained theoretically, we lack sufficient research information on the empirical analyses of this subject. What mainly exist are impact analyses at the household level, such as analyses of the effect of microfinance on household income or consumption. There is a consensus that microfinance decreases the consumption volatility of households and leads to consumption smoothing and increased production (Cuong et al., 2007; Khandker, 1998; Parker \& Nagarajan, 2001; Zaman, 2001). However, impact analyses such as the effect of microfinance on income or poverty reduction are controversial, provide different results for different subjects, and lack universality. For example, Pitt and Khandker (1998) show that microfinance increases household consumption, while Morduch (1999) indicates that microfinance does not have a significant impact on consumption (cited in Roodman \& Morduch, 2009). Mosley and Hulme (1998) show that microfinance does not offer loans to the poorest of people.

Yet, only a few impact analyses have been performed at the macro level, and there have been few studies on the impact of microfinance on inequality. The effect of microfinance on inequality has been examined only within a particular country; no cross-country analyses have been conducted thus far. Cuong et al. (2007) analyzed the Vietnam Bank for Social Policies and concluded that it lowers inequality, but its effect is insignificant. Mahjabeen (2008) used the general equilibrium (CGE) model to show that microfinance in Bangladesh lowers inequality. Yet there is no sufficient empirical information on the effect of microfinance on inequality, so further analysis is required. 


\section{Mll Macrothink}

Research in Applied Economics

ISSN 1948-5433

2009, Vol. 1, No. 1: E14

This paper provides a detailed empirical cross-country analysis of 61 developing countries, concerning the impact of microfinance on inequality. Since the 1980s, microfinance has grown with each passing year and plays an important role in the financial markets of many developing countries. Although microfinance is expected to significantly affect macro variables, there has not been enough empirical research on impact analysis at the macro level, such as the effect of microfinance on inequality. We expect microfinance to have an equalizing effect, and we provide a detailed empirical analysis of this concept.

The contribution of this paper is twofold. Firstly, while previous studies have analyzed whether financial depth as a whole lowers inequality, our study considers microfinance as a financial system that directly affects inequality and focuses on the relationship between microfinance and inequality. We explain the role of microfinance as a tool for financial depth endowed with an equalizing effect. Secondly, while previous empirical studies conducted analyses of individual nations and found different results for different subjects or countries, our analysis provides a more universal result by using the cross-country methodology. Thus, our study will be significant if we can (1) demonstrate the universality of the impact of microfinance, (2) indicate impact assessment at the macro level, and (3) explain the role of microfinance in financial development.

The structure of this paper is as follows. The next section describes the model used in our study. Section 3 provides information about the data. Section 4 presents the empirical results, and the final section concludes the paper.

\section{Model}

In accordance with recent empirical studies such as that of Milanovic (2002), we use the cross-country regression methodology to examine the impact of microfinance on inequality in developing countries. Our empirical analysis is based on data from 61 developing countries. The empirical specifications are as follows:

Model 1: $\quad y_{i}=\alpha+\beta M_{i}+\eta X_{i}+u_{i}$,

Model 2: $\quad y_{i}=\alpha+\beta \log M_{i}+\eta X_{i}+u_{i}$,

where $y_{i}$ indicates the inequality measure; $M_{i}$ represents the degree of microfinance intensity; $X_{i}$ is the vector of control variables; and $u_{i}$ denotes random disturbance ( $i$ : country).

Model 1 is the specification that includes microfinance intensity for the purpose of examining the effects of microfinance on inequality. Model 2 is the specification in which the logarithm of microfinance intensity is employed to examine the equalizing effect of microfinance. These specifications are used to see if our empirical results are robust to the choice of microfinance intensity.

The degree of microfinance intensity is included in order to assess the impact of microfinance on inequality. We employ the number of MFIs and the number of borrowers in a country as the measures of microfinance intensity. We can expect that microfinance eases the credit constraints on the poor, thus decreasing inequality. 


\section{MlMacrothink}

Research in Applied Economics

ISSN 1948-5433

2009, Vol. 1, No. 1: E14

The analysis also includes control variables such as the logarithm of GDP per capita and its square term, the inflation rate, the democracy index, and some regional dummies. We assume that a higher income level increases inequality, but its effect declines after a certain point. Kuznets' inverted-U hypothesis points out that inequality increases until a country's income reaches a certain level, and after the turning point, inequality declines. (Note 1) We therefore include the logarithm of GDP per capita and its square terms in the model as well, in accordance with previous studies that also include these variables in their models.

Furthermore, our analysis includes openness in order to assess the impact of openness on inequality. We employ a trade (export and import) to GDP ratio as the measure of openness, following empirical studies such as Milanovic (2002) and Wade (2004). The neoclassical theory shows that openness results in economic development, increases employment, and lowers inequality through improved resource allocation and technology transfer. Furthermore, the Heckscher-Ohlin-Samuelson model indicates that openness increases the demand of low-skilled labor in poor countries, since developing nations export low-skilled labor-intensive products, which lowers inequality. On the other hand, various studies show that openness worsens inequality (Freenstra \& Hanson, 1996; Wood, 2002; Gaston \& Nelson, 2002; Zhu \& Trefler, 2005; Silva, 2007; Dreher \& Gaston, 2008). According to their research, openness increases the demand of high-skilled labor in developing countries, since it requires a higher level of economic activity through outsourcing and foreign direct investment (FDI). These empirical results have also been controversial.

We expect higher inflation to be associated with higher inequality because high inflation mainly harms the poor and increases the number of poor people. We also assume that inequality declines as democracy intensifies, following standard political economy theories (Gradstein et al., 2001). Furthermore, our model includes regional dummy variables, including the dummies of South Africa (South Africa $=1$, others $=0$ ), Eastern Europe and Central Asia (Eastern Europe and Central Asia = 1, others =0), the Middle East and North Africa (Middle East and North Africa = 1, others = 0), and Latin America (Latin America = 1, others $=0$ ), in order to examine the differences in inequality among these regions. (Note 2)

\section{Data}

This paper uses cross-sectional data from 61 developing countries, which is obtained from World Development Indicators (WDI) published by the World Bank. We use the 2007 cross-sectional data for regression, using the number of MFIs in a country as the measure of microfinance intensity. We also use the 2005-2007 pooled data for regression, using the number of borrowers in a country as the measure of microfinance intensity. Since the World Bank publishes inequality data almost every five years and its year of publication differs for various countries, the data for our analysis is the earliest available data, ranging from 2003 to 2007. The data on the number of MFIs in each country is obtained from the Microcredit Summit Campaign. (Note 3) The democracy index that we employ is Institutionalized Democracy, obtained from Marshall and Jaggers (2009). Real GDP per capita is expressed as the constant US\$2000. The measure of openness is calculated as the trade to GDP ratio, i.e., the ratio of the sum of export of goods and services and import of goods and services to GDP 
(\% of GDP). Inflation rate is calculated using the GDP deflator (annual \%). Definitions and summary statistics are shown in Table 1.

Table 1. Variable Definitions and Summary Statistics

\begin{tabular}{|c|c|c|c|}
\hline Variable & Definition & Mean & $\begin{array}{l}\text { Standard } \\
\text { Deviation }\end{array}$ \\
\hline Inequality & Gini coefficient & 41.862 & 7.886 \\
\hline Number of MFIs & $\begin{array}{l}\text { Number of microfinance institutions (MFIs) in } \\
\text { a country }\end{array}$ & 50.565 & 119.091 \\
\hline Number of Borrowers & $\begin{array}{l}\text { Number of borrowers who borrow from MFIs } \\
\text { in a country }\end{array}$ & 101910 & 364663 \\
\hline $\begin{array}{l}\text { Logarithm of GDP per } \\
\text { capita }\end{array}$ & $\begin{array}{l}\text { Logarithms of GDP per capita (constant } \\
\text { US\$2000) }\end{array}$ & 6.906 & 1.081 \\
\hline $\begin{array}{l}\text { Trade (Export + Import) } \\
\text { to GDP Ratio }\end{array}$ & $\begin{array}{l}\text { Export of goods and services plus import of } \\
\text { goods and services (\% of GDP) }\end{array}$ & 84.810 & 35.115 \\
\hline Inflation rate & Inflation, GDP deflator (annual \%) & 8.139 & 5.682 \\
\hline Democracy index & Institutionalized democracy & 5.284 & 3.454 \\
\hline South Africa & $\begin{array}{l}\text { South Africa Dummy } \\
\text { South Africa = } 1 \text {, Others }=0\end{array}$ & 0.318 & 0.468 \\
\hline $\begin{array}{l}\text { Eastern Europe and } \\
\text { Central Asia }\end{array}$ & $\begin{array}{l}\text { Eastern Europe and Central Asia Dummy } \\
\text { Eastern Europe and Central Asia = } 1 \text {, } \\
\text { Others = } 0\end{array}$ & 0.224 & 0.419 \\
\hline $\begin{array}{l}\text { Middle East and North } \\
\text { Africa }\end{array}$ & $\begin{array}{l}\text { Middle East and North Africa Dummy } \\
\text { Middle East and North Africa }=1 \text {, Others }=0\end{array}$ & 0.082 & 0.277 \\
\hline Latin America & $\begin{array}{l}\text { Latin America Dummy } \\
\text { Latin America }=1 \text {, Others }=0\end{array}$ & 0.212 & 0.411 \\
\hline
\end{tabular}

\section{Sources:}

Number of MFIs in a country: Microcredit Summit Campaign (http://www.microcreditsummit. org)

Number of borrowers in a country: Trend Lines 2005-2007 MFI Benchmarks (Microfinance Information eXchange) (http://www.themix.org/publication/trend-lines-2005-2007-mfibenchmarks)

Democracy index: Marshall \& Jagger (2009)

Others: World Development Indicators (World Development Bank)

\section{Empirical Results}

Table 2 displays the empirical results of the regression using the number of MFIs as the degree of microfinance intensity. The first column presents the results of Model 1, which employs the number of MFIs as the degree of microfinance intensity, and the second column presents the results of Model 2, which employs the logarithm of the number of MFIs as the degree of microfinance intensity. Our results show that microfinance intensity measures may 
be significantly negative for both specifications, i.e., -0.0098 for Model 1 and -1.0998 for Model 2, indicating that microfinance lowers inequality. It can therefore be argued that microfinance may have a significant equalizing effect.

With regard to control variables, the logarithm of GDP per capita is estimated to be significantly positive, i.e., 18.8718 for Model 1 and 21.6184 for Model 2, and its square term is estimated to be significantly negative, i.e., -1.3799 for Model 1 and -1.5796 for Model 2 . Thus, inequality worsens as a country develops, but after a certain development level, inequality declines. This supports Kuznets’ inverted-U hypothesis.

Table 2. Empirical Results

\begin{tabular}{|c|c|c|c|c|}
\hline \multirow[b]{2}{*}{ Variable } & \multicolumn{2}{|c|}{ Model 1} & \multicolumn{2}{|c|}{ Model 2} \\
\hline & Coefficient & $p$-value & Coefficient & $p$-value \\
\hline Number of MFIs & -0.0098 & 0.055 & & \\
\hline Logarithm of number of MFIs & & & -1.0998 & 0.094 \\
\hline Logarithm of GDP per capita & 18.8718 & 0.028 & 21.6184 & 0.020 \\
\hline $\begin{array}{l}\text { Square of logarithm of GDP per } \\
\text { capita }\end{array}$ & -1.3799 & 0.020 & -1.5796 & 0.015 \\
\hline Trade to GDP ratio & -0.0043 & 0.820 & -0.0085 & 0.675 \\
\hline Inflation rate & -0.0753 & 0.557 & -0.0821 & 0.544 \\
\hline Democracy & 0.3258 & 0.144 & 0.2917 & 0.198 \\
\hline South Africa & 2.2492 & 0.343 & 2.9279 & 0.209 \\
\hline Eastern Europe and Central Asia & -6.8877 & 0.004 & -8.1182 & 0.005 \\
\hline Middle East and North Africa & -2.9863 & 0.338 & -3.1997 & 0.322 \\
\hline Latin America & 11.7369 & 0.000 & 12.3188 & 0.000 \\
\hline Constant & -23.0968 & 0.453 & -29.1001 & 0.370 \\
\hline Number of Observations & & 61 & & 59 \\
\hline$F(10,50)$ & & 17.490 & & 16.540 \\
\hline Prob $>$ F & & 0.000 & & 0.000 \\
\hline Adjusted R-squared & & 0.733 & & 0.728 \\
\hline Root MSE & & 4.246 & & 4.319 \\
\hline
\end{tabular}

Note: Number of MFIs in a country is used as the measure of microfinance intensity.

Moreover, the dummy of Eastern Europe and Central Asia is significantly negative, i.e., -6.8877 for Model 1 and -8.1182 for Model 2, while that of Latin America is significantly positive, i.e., 11.7369 for Model 1 and 12.3188 for Model 2. Thus, inequality is relatively low in Eastern Europe and Central Asia, while it is relatively high in Latin America.

Table 3 displays the result of the regression using the number of borrowers in a country as the degree of microfinance intensity. The first column presents the result of Model 1, which employs the number of MFIs as the degree of microfinance intensity, and the second column 
presents the result of Model 2, which employs the logarithm of the number of MFIs as the degree of microfinance intensity. The results clearly show that the coefficient on the number of borrowers and the coefficient on the logarithm of the number of borrowers are significantly negative in both specifications, i.e., -0.0000034 for Model 1 and -0.7974 for Model 2. Thus, microfinance leads to a decline in inequality, indicating the clear equalizing effect of microfinance.

With regard to control variables, the logarithm of GDP per capita is estimated to be significantly positive, i.e., 16.5793 for Model 1 and 14.6090 for Model 2, and its square term is estimated to be significantly negative, i.e., -1.2671 for Model 1 and -1.1567 for Model 2. Thus, Kuznets' inverted-U hypothesis is supported in this case as well.

Table 3. Empirical Results

\begin{tabular}{|c|c|c|c|c|}
\hline \multirow[b]{2}{*}{ Variable } & \multicolumn{2}{|c|}{ Model 1} & \multicolumn{2}{|c|}{ Model 2} \\
\hline & Coefficient & $p$-value & Coefficient & $p$-value \\
\hline Number of borrowers & -0.0000034 & 0.004 & & \\
\hline Logarithm of number of borrowers & & & -0.7974 & 0.018 \\
\hline Logarithm of GDP per capita & 16.5793 & 0.013 & 14.6090 & 0.031 \\
\hline $\begin{array}{l}\text { Square of logarithm of GDP per } \\
\text { capita }\end{array}$ & -1.2671 & 0.007 & -1.1567 & 0.014 \\
\hline Trade to GDP ratio & -0.0052 & 0.669 & -0.0098 & 0.479 \\
\hline Inflation rate & -0.1257 & 0.183 & -0.1605 & 0.101 \\
\hline Democracy & 0.2761 & 0.189 & 0.4304 & 0.033 \\
\hline South Africa & 2.5396 & 0.104 & 2.7347 & 0.083 \\
\hline Eastern Europe and Central Asia & -4.5746 & 0.001 & -4.2704 & 0.003 \\
\hline Middle East and North Africa & -0.8992 & 0.715 & 1.0717 & 0.651 \\
\hline Latin America & 14.0992 & 0.000 & 14.7733 & 0.000 \\
\hline Constant & -14.1037 & 0.544 & 1.2118 & 0.961 \\
\hline Number of Observations & & 120 & & 120 \\
\hline $\mathrm{F}(10,109)$ & & 45.570 & & 44.240 \\
\hline Prob $>F$ & & 0.000 & & 0.000 \\
\hline Adjusted R-squared & & 0.789 & & 0.784 \\
\hline Root MSE & & 4.024 & & 4.072 \\
\hline
\end{tabular}

Note: Number of borrowers in a country is used as the measure of microfinance intensity.

Moreover, the dummy of Eastern Europe and Central Asia is significantly negative, i.e., -4.5746 for Model 1 and -4.2704 for Model 2, while that of Latin America is significantly positive, i.e., 14.0992 for Model 1 and 14.7733 for Model 2. Further, the dummy variable for South Africa is significantly estimated to be 2.7347 for Model 2. Thus, inequality is relatively 
low in Eastern Europe and Central Asia, while it is relatively high in Latin America and South Africa.

Democracy is positively significant in Model 2, which is incompatible with our prediction, although our result is consistent with previous empirical literature (Gradstein et al., 2001).

\section{Conclusion}

This paper provides a cross-country empirical study of 61 developing countries, concerning the impact of microfinance on inequality. We show that microfinance plays an important role in creating a financial system endowed with the equalizing effect. Until now, only a few single-country analyses of the impact of microfinance on inequality have been performed; a cross-country analysis has not been conducted thus far. To the best of our knowledge, our study is the first one to indicate the universality of the equalizing effect of microfinance by applying the cross-country methodology. Moreover, we contribute to the research accumulation of the impact assessment of microfinance at the macro level, which has seldom been analyzed.

The main results of the empirical analysis in this paper are as follows:

(1) Microfinance has a significant equalizing effect.

(2) Our empirical results support Kuznets’ inverted-U curve.

As such, our empirical results confirm that microfinance lowers inequality, and that it can be used as an effective redistribution tool. Moreover, we found that economic development lowers inequality after a country's income reaches a certain level, while economic growth increases inequality up to a certain level of economic development, such as occurs in developing countries. Apparently, economic growth in developing countries does not have a significant trickle-down or equalizing effect, and it significantly increases inequality. Accordingly, poor countries need to focus more on the equalizing effect of microfinance.

The high inequality in developing countries is largely due to credit constraints on the poor or to financial market failure, which solely besieges wealthy people. Microfinance can effectively provide loans to the poor with a high repayment rate using its unique technique; it is expected to ease the credit constraints on the poor and hence lower inequality. Since microfinance is believed to be unable to finance itself, and since it relies on external support such as subsidies, governments need to develop microfinance markets with sufficient assistance. The financial sector should not depend on the market force unconditionally, and a market intervention that creates a financial system specially designed to redistribute wealth to the poor is required. Microfinance can be an effective tool with regard to this requirement. Microfinance also allows the poor not only to obtain loans but also to increase their productivity through borrowing activity with training, which leads to the development of a social system in poor countries. Thus, microfinance copes with market failure in order to prompt well-balanced financial development, leading to economic growth and improvement of social welfare. 


\section{Acknowledgement}

We would like to thank the editor of this journal, three anonymous referees, Fumiharu Mieno, and Nobuaki Matsunaga for their helpful comments and suggestions.

\section{References}

Ahlin, C., \& Jiang, N. (2008). Can micro-credit bring development? Journal of Development Economics, 86(1), pp.1-21.

Beck, T., Demirgüç-Kunt, A., \& Levine, R. (2004). Finance, inequality and poverty: Cross-country evidence. NBER working paper 10979.

Cuong, N. V., Bigman, D., Van den Berg, M., \& Thieu, V. (2007). Impact of micro-credit on poverty and inequality: The case of the Vietnam Bank for Social Policies. Paper submitted to “Microfinance: What Do We Know?” December 7-8, 2007, Groningen, Netherlands.

Dreher, A., \& Gaston, N. (2008). Has globalization increased inequality? Review of International Economics, 16(3), pp.516-536.

Feenstra, R., \& Hanson, G. (1996). Globalization, outsourcing, and wage inequality. American Economic Review, 86, pp.240-245.

Gaston, N., \& Nelson, D. (2002). Integration, foreign direct investment and labour markets: Microeconomic perspectives. The Manchester School, 70(3), pp.420-459.

Gradstein, M., Milanovic, B., \& Ying, Y. (2001). Democracy and income inequality: An empirical analysis. CESifo working paper 411.

Green, C. J., Kirkpatrick, C. H., \& Murinde, V. (2006). Finance for small enterprise growth and poverty reduction in developing countries. Journal of International Development, 18(7), pp.1017-1030.

Greenwood, J., \& Jovanovic, B. (1990). Financial development, growth, and the distribution of income. Journal of Political Economy, 98(5), pp.1076-1107.

Jalilian, H., \& Kirkpatrick, C. (2002). Financial development and poverty reduction in developing countries. International Journal of Finance \& Economics, 7(2), pp.97-108.

Kai, H., \& Hamori, S. (2009). Globalization, financial depth, and inequality in Sub-Saharan Africa. Economics Bulletin, 29(3), pp.2025-2037.

Khandker, S. R. (1998). Fighting poverty with microcredit: Experience in Bangladesh. New York: Oxford University Press.

Kuznets, S. (1955). Economic growth and income inequality. American Economic Review, 45(1), pp.1-28.

Li, H., Squire, L., \& Zou, H. F. (1998). Explaining international and intertemporal variations in income inequality. Economic Journal, 108(446), pp.26-43.

Mahjabeen, R. (2008). Microfinancing in Bangladesh: Impact on households, consumption 
and welfare. Journal of Policy Modeling, 30(6), pp.1083-1092.

Marshall, M. G., \& Jaggers, K. (2009). Polity IV project: Political regime characteristics and transitions. Annual Time-series 1800-2007. [Online] Available: http://www.systemicpeace. org/inscr/inscr.htm.

Milanovic, B. (2002). Can we discern the effect of globalization on income distribution? Evidence from household budget survey. World Bank Policy Research, working paper 2876.

Morduch, J. (1998). Does microfinance really help the poor? New evidence from flagship programs in Bangladesh. New York University. [Online] Available: http://www.nyu.edu/ projects/morduch/documents/microfinance/Does_Microfinance_Really_Help.pdf.

Mosley, P., \& Hulme, D. (1998). Microenterprise finance: Is there a conflict between growth and poverty alleviation? World Development, 26(5), pp.783-790.

Parker, J., \& Nagarajan, G. (2001). Can microfinance meet the poor's needs in times of natural disaster? Microenterprise Best Practices, Development Alternatives, Inc.

Pitt, M. M., \& Khandker, S. R. (1998). The impact of group-based credit on poor households in Bangladesh: Does the gender of participants matter? Journal of Political Economy, 106(5), pp.958-96.

Roodman, D., \& Morduch, J. (2009). The impact of microcredit on the poor in Bangladesh: Revisiting the evidence. Center for Global Development, working paper 174.

Silva, J. A. (2007). Trade and income inequality in a less developed country: The case of Mozambique. Economic Geography, 83(2), pp.111-136.

Stiglitz, J. (1998). The role of the state in financial markets. Proceedings of the World Bank Annual Conference on Development Economics, Washington, DC: The World Bank.

Wade, R. H. (2004). Is globalization reducing poverty and inequality? World Development, 32(4), pp.567-589.

Wood, A. (2002). Globalization and wage inequalities: A synthesis of three theories. Weltwirtschaftliches Archiv, 138(1), pp.54-82.

World Bank. (2001). World development report 2000/2001. New York: Oxford University Press.

Zaman, H. (2001). Assessing the poverty and vulnerability impact of micro-credit in Bangladesh: A case study of BRAC. Background paper for the WDR 2000/2001.

Zhu, S. C., \& Trefler, D. (2005). Trade and inequality in developing countries: A general equilibrium analysis. Journal of International Economics, 65(1), pp.21-48.

\section{Notes}

Note 1. See Kuznets (1955).

Note 2. The base region is Asia. 
Note 3. http://www.microcreditsummit.org 